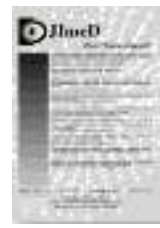

Jurnal Imejing Diagnostik (JImeD) 6 (2020) 86-90

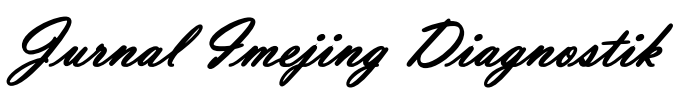

e-ISSN 2621-7457, p-ISSN 2356-301X

\title{
Analisis Prosedur Pemeriksaan Magnetic Resonance Spectroscopy (MRS) pada Kasus Tumor Otak
}

\author{
Putri Susilowati ${ }^{1}$, Widya Nurmayanti ${ }^{2}$ \\ ${ }^{1}$ Instalasi Radiologi RSUD Prof. Dr. Margono Soekarjo, Indonesia \\ ${ }^{2}$ Poltekkes Kemenkes Semarang, Indonesia \\ Corresponding author: Widya Nurmayanti \\ E-mail: widyanurma04@gmail.com
}

Received: June $13^{\text {rd }}, 2020$; Revised: June $17^{\text {th }}, 2020$; Accepted: June $30^{\text {th }}, 2020$

\begin{abstract}
Background: Magnetic Resonance Spectroscopy (MRS) is a method for measuring or assessing changes in the chemical elements of brain tissue in abnormalities such as tumours, stroke, epilepsy, metabolic disorder, infections, and neurodegenerative disease. MRS sequences require techniques to suppress fat and water signals, so the value of metabolic elements such as NAA < Choline, Creatine, Lipids, and Lactate not been covered by fat and water. The peak amplitude of metabolic elements in MRS depends on the parameter used in the MRS sequences especially TE. Some studies suggest that variation and combinations of TE can provide more complete information on metabolite element, and can even be used to grading tumour stages. Methods: Type of this research is a qualitative study with an observational approach. Data collection was conducted in June 2019 at Radiology Department with observation method, unstructured interview, and documentation related to Magnetic Resonance Spectroscopy procedures. Data processing and analysis are carried out descriptively related to the result of observation, interview, and documentation.

Results: The Head MR Spectroscopy examination procedure is a follow-up procedure of contrast MRI of the head. The main metabolite elements assessed on MRS are NAA, Choline, and Creatine, while those calculated and analyzed are the Area Under Cover (AUC) Integrals which are a collection of NAA and Choline signals. MRS sequences use Multi Voxel Spectroscopy (MVS). Chemical Shift Imaging (CSI) is used to suppress fat and water signals. TE parameter used in MRS sequences is only intermediate $135 \mathrm{ms.}$
\end{abstract}

Keywords: MRS; TE; MRI Brain Tumor.

\section{Pendahuluan}

Aplikasi Nuclear Magnetic Resonance (NMR) dalam bidang biomedis dibedakan menjadi dua kelompok yaitu Magnetic Resonance Imaging dan Magnetic Resonance Spectroscopy. Magnetic Resonance Imaging (MRI) merupakan prosedur atau metode pemeriksaan non invasive menggunakan resonansi magnetik untuk mengetahui lokasi secara anatomis dari suatu kelainan patologis, Sedangkan Magnetic Resonance Spectroscopy (MRS) adalah suatu prosedur pemeriksaan non invasif menggunakan resonansi magnetik untuk membandingkan komposisi kimiawi antara jaringan normal dan jaringan yang tidak normal. Pemeriksaan MRS dilakukan untuk mendiagnosa kelainan berupa tumor, epilepsi dan perubahan jaringan yang mungkin terjadi pada pasien-pasien stroke (Tognarelli et al., 2015).

MRS merupakan protokol tambahan setelah protokol MRI Kepala rutin dengan media kontras. MRS merupakan metode untuk mengukur atau menilai perubahan unsur kimia jaringan otak pada kelainan patologis berupa tumor, stroke, epilepsy, metabolic disorder, infeksi, dan penyakit neurodegeneratif. Spektrum MRS tidak langsung dilengkapi dengan hasil diagnosis, dibutuhkan intepretasi dan harus selalu dikorelasikan dengan citra MRI konvensional (Horská \& Barker, 2010).

Nuclei yang sering digunakan adalah ${ }^{1} \mathrm{H}$ (proton), ${ }^{23} \mathrm{Na}$ (sodium), dan ${ }^{31} \mathrm{P}$ (phosphor). Proton spectroscopy menghasilkan SNR yang lebih tinggi 
dibandingkan dengan sodium dan phosphor. Pada MRI, total sinyal dari seluruh proton pada tiap voxel digunakan untuk menghasilkan citra, sehingga puncak grafik spektroskopi lemak dan air akan menjadi sangat dominan sehingga metabolit unsur kimia yang lain tidak terlihat. Sedangkan pada MRS gambaran puncak grafik spektroskopi lemak dan air tidak diperlukan, maka dilakukan penekanan terhadap sinyal lemak dan air dengan menggunakan teknik Chemical Shift Imaging (CSI). Untuk mendapatkan penilaian unsur kimia tumor secara akurat, voxel pada CSI matrix harus ditempatkan tepat di area tumor yang mengalami penguatan (enhancement), hindari area nekrosis, perdarahan, kalsifikasi, atau kista (Horská \& Barker, 2010).

Amplitudo puncak MRS tergantung pada parameter yang digunakan pada sekuens MRS terutama Time Repetition (TR) dan Time Echo (TE). Signal loss karena $\mathrm{T} 1$ relaxation dan $\mathrm{T} 2$ decay harus dihindari, untuk itu parameter terbaik adalah dengan menggunakan TR $2000 \mathrm{~ms}$ dan TE yang pendek yaitu 30-35 ms. TE yang panjang akan mengatenuasi sinyal dari resonansi molekul makro yang tidak diinginkan, seperti dari lipid (Tognarelli et al., 2015). Carlos Majos et al menyebutkan bahwa TE yang pendek (35 ms) mampu menghasilkan spektrum yang dapat digunakan untuk klasifikasi tumor sedikit lebih baik dibandingkan dengan TE yang panjang (136 ms) pada hampir semua jenis tumor otak. Tetapi hanya pada kasus meningioma, TE panjang menghasilkan sensitivitas dan spesifisitas yang lebih baik dibandingkan TE yang pendek (Barker, 2001). Sedangkan menurut Radwa Kamel et al, kombinasi antara short TE (35 ms) dan intermediate TE (135 ms) dengan menggunakan dua localization menghasilkan akurasi yang lebih baik dalam grading neoplasma otak dibandingkan dengan penggunaan TE yang berbeda secara terpisah (Naser et al., 2016). Perbedaan parameter menentukan hasil spektrum dan juga informasi yang dapat disimpulkan dari spektrum tersebut (Barker, 2001).

Metabolisme kimia pada otak yang mucul pada spectrum MRS akan muncul pada nilai dengan satuan parts per million ( $\mathrm{ppm}$ ) yang spesifik, dan setiap nilai yang muncul merefleksikan proses seluler dan biokimia. N-acetylaspartate (NAA) merupakan neural marker, nilainya akan turun ketika ada kelainan patologis yang merusak sistem neuron. Creatine menunjukkan ukuran energi sel. Sedangkan choline menunjukkan ukuran peningkatan perubahan seluler dimana pada tumor dan proses peradangan tingkat perubahan seluler meningkat. Spektrum MRS normal menunjukkan dari kanan ke kiri NAA, creatine, choline dan myoinositol. Metode yang umum digunakan untuk menganalisis spectrum secara klinis adalah dengan melihat rasio metabolit yaitu NAA/Cr, NAA/Cho, dan $\mathrm{Cho} / \mathrm{Cr}$. Nilai normal dan abnormal dari rasio metabolit adalah NAA/Cr $(2,0 /<1,6)$, NAA/Cho $(1,6 /<1,2)$, dan Cho/Cr (1,2/>1,5) (Barker, 2001).

MR Spectroskopi memiliki kelebihan antara lain, mampu mendeteksi adanya infiltrasi sel kanker diluar tepi tumor, dapat menjadi panduan bagi dokter spesialis bedah untuk mendapatkan sampel jaringan tumor yang paling aktif metabolismenya ketika dilakukan biopsi sehingga hasil pemeriksaan patologi anatomi lebih akurat dalam menentukan stadium kanker, dan mampu membedakan reccurrence tumor dan jaringan yang muncul akibat efek terapi radiasi dimana pada reccurence tumor spektrum NAA, creatine, dan choline rendah, sedangkan pada nekrosis karena radiasi spektrum lipid dan lactate mengalami peningkatan (Ionin \& Ershov, 2014). Keterbatasan MRS adalah spectrum dari RNA, DNA, sebagian besar protein, enzim, dan phospholipid, juga beberapa neuro transmitter tidak muncul (Hamsini et al., 2018).

Tumor otak adalah pertumbuhan sel-sel abnormal di dalam atau disekitar otak secara tidak wajar dan tidak terkendali. Tumor otak merupakan salah satu bagian dari tumor pada sistem syaraf, disamping tumor spinal dan tumor syaraf perifer. Ada beberapa jenis tumor otak yang dibedakan kedalam dua kelompok berdasarkan perkembangannya, yaitu tumor jinak dan tumor ganas (Wh, 2010).

Pada kasus tumor otak, MRS dapat digunakan untuk menilai stadium keganasan. Stadium keganasan yang meningkat ditandai dengan nilai NAA dan creatine yang menurun, choline, lactate dan lipid yang naik. Penurunan NAA dikarenakan tumor merusak neuron, sedangkan penurunan creatine disebabkan karena aktivitas metabolik tumor yang tinggi menyebabkan terkurasnya energi yang tersimpan dalam sel(Gupta et al., 2000). Tumor dengan perkembangan yang sangat aktif dan cepat akan menyebabkan nilai choline naik (Gupta et al., 2000). Lipid ditemukan pada area tumor yang mengalami nekrosis, sedangkan lactate muncul ketika tumor mulai mengontrol suplai darah dan 
menggunakan glikolisis anaerob (Herholz et al., 1992).

\section{Metode}

Jenis penelitian ini adalah penelitian deskriptif analitik dengan pendekatan observasi. Pengambilan data dilakukan pada bulan Juni 2019 menggunakan pesawat MRI SIEMENS MAGNETOM AERA berkekuatan 1,5 Tesla. Sampel pasien yang digunakan pada kajian ini adalah pasien MRS dengan diagnose klinis tumor otak.

Pengambilan data dilakukan melalui observasi, wawancara dengan radiografer, dan dokumentasi pelaksanaan pemeriksaan MR Spektroskopi Kepala pada kasus tumor otak. Deskripsi dan analisis data dilakukan berdasarkan hasil observasi, wawancara serta dokumentasi untuk kemudian diambil kesimpulan dan saran.

\section{Hasil dan Pembahasan}

Prosedur pemeriksaan MRS pada kasus tumor otak adalah sebagai berikut :

1. Persiapan Pasien

Pasien harus memenuhi beberapa persyaratan persiapan terlebih dahulu, antara lain :

a. Melakukan pemeriksaan ureum dan creatinine untuk mengetahui kondisi ginjal pasien terkait dengan penggunaan media kontras. Hasil pemeriksaan ureum dan creatinine harus normal.

b.Puasa 6-8 jam sebelum pemeriksaan untuk mengantisipasi terjadinya afiksi ketika terjadi muntah akibat reaksi alergi media kontras.

c.Pasien diberikan penjelasan tentang prosedur dan tujuan pemeriksaan serta efek samping yang terjadi dari prosedur pemeriksaan, kemudian diminta untuk mengisi lembar persetujuan tindakan (inform consent).

d.Dilakukan screening terhadap pasien sesuai dengan checklist screening pasien yang telah tersedia meliputi riwayat claustrophobia, tindakan operasi yang pernah dilakukan oleh pasien, penggunaan material logam dalam tubuh pasien seperti plat tulang, pacemaker, dan kawat gigi sebagai upaya untuk menjamin keselamatan pasien. e. Dilakukan skin test sebelum injeksi media kontras untuk mengetahui potensi terjadinya reaksi alergi terhadap media kontras.

2. Persiapan Alat dan Bahan

Alat dan bahan yang digunakan, antara lain :

a. Modalitas MRI Siemens Magnetom Aera 1,5 $\mathrm{T}$

b. Head Coil

c. Oksigen

d. Media kontras Gadodiamide $(8 \mathrm{ml})$

e. Spuit $20 \mathrm{cc}$

f. Spuit $1 \mathrm{cc}$

g. Wing Needle No 21 atau 23

h. Head Set

i. Selimut

3. Prosedur Pemeriksaan

Pemeriksaan MRS menggunakan modalitas MRI Siemens Magnetom Aera 1,5 Tesla, merupakan pemeriksaan lanjutan dari MRI Kepala tanpa kontras dan dengan kontras. Rangkaian sekuens protokol pemeriksaan MR Spektroskopi Kepala secara lengkap adalah sebagai berikut :

1. Head Scout

2. DWI Transversal

3. T1 Sagital Tanpa Kontras

4. T1 Transversal Tanpa Kontras

5. T2 FLAIR Tanpa Kontras

6. T2 Transversal Tanpa Kontras

7. T2 Coronal Tanpa Kontras

8. MRA

9. Perfusi

10. 2 SWI

11. T1 Sagital Dengan Kontras

12. T1 Transversal Dengan Kontras

13. T1 Coronal Dengan Kontras

14. MR Spectroscopy

Parameter yang digunakan pada sekuens MRS yaitu TR 1500 ms, TE 135 ms, Flip Angle 90, average 4. Parameter TE yang digunakan dalam prosedur pemeriksaan MR Spektroskopi hanya satu yaitu intermediate TE (135 ms). Teknik pemeriksaan MRS menggunakan multi voxel spectroscopy (MVS) dengan Chemical Shift Imaging (CSI) untuk menekan spektrum lemak dan air. CSI matriks ditempatkan pada area lesi dengan mengatur semua area lesi, area pinggir lesi, area odema sekitar lesi, dan jaringan 
normal disekitar lesi tercover secara kontra lateral. Penempatan CSI matriks harus menghindari area udara dan tulang agar tidak mempengaruhi hasil spektrum metabolit tumor. Saturasi band ditempatkan disekeliling CSI matriks baik dari potongsn transversal, sagital, maupun coronal. Full Weight Half Maximum (FWHM) sebagai indikator homogenitas voxel harus diatur $<15$ sehingga grafik spektrum yang dihasilkan akan tepat yang ditandai dengan grafik spectrum tajam dimana kaki grafik spektrum choline dan creatine terpisah.

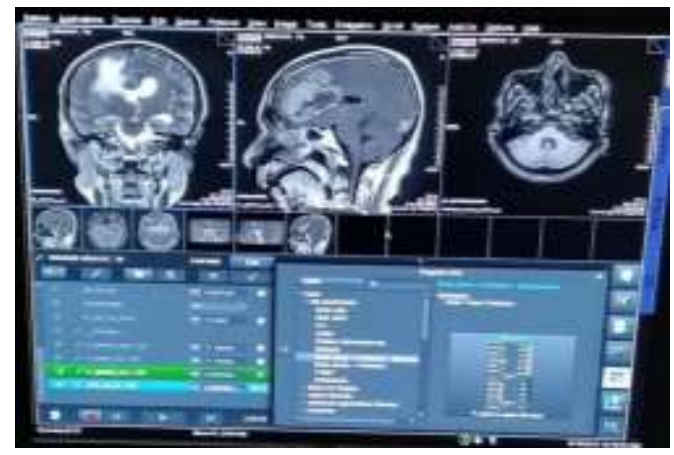

Gambar 1. Penambahan Sekuens MR Spectroscopy setelah MRI dengan Kontras

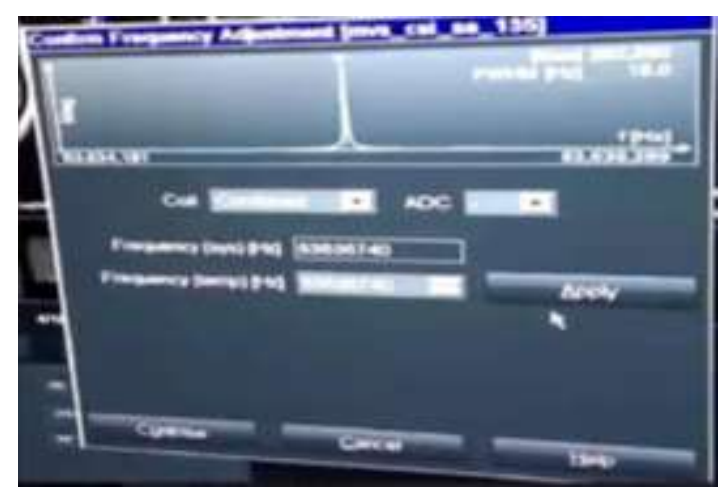

Gambar 2. Pengaturan FWHM

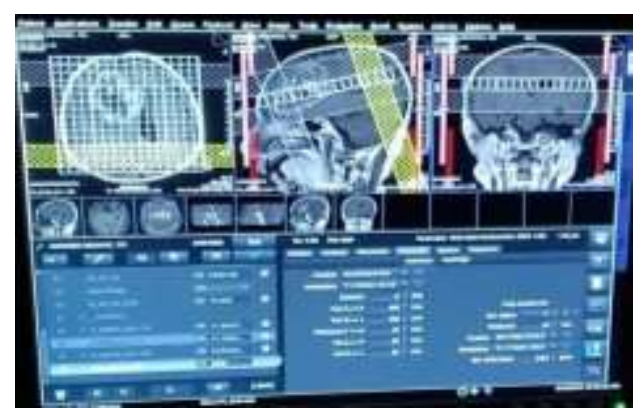

Gambar 3. Pengaturan Penempatan CSI Matriks dan Saturation Band

Pada tahap post processing MR Spektroskopi, dibuat grafik spektrum spektroskopi dengan melakukan pengukuran nilai tiap voxel pada CSI matrix, maka akan muncul spektrum dan nilai-nilai metabolit. Tiap voxel memiliki nilai metabolit yang berbeda, untuk itu voxel pada area tumor, tepi tumor, area udema tumor, area nekrosis, dan area normal harus dibuat grafik spektrumnya dan dinilai unsur metabolitnya, lalu data disimpan untuk kemudian dianalisa dan diekspertise.

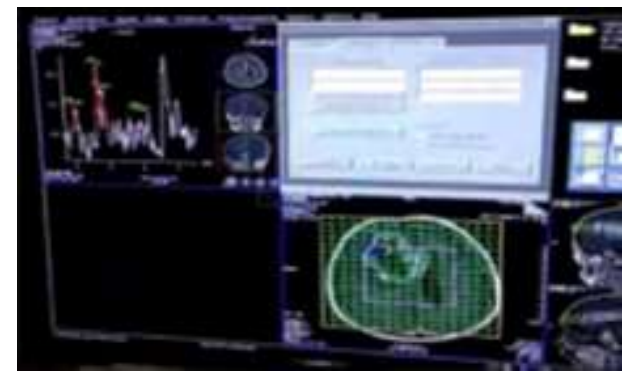

Gambar 4. Hasil pengukuran dari salah satu voxel pada CSI matriks menunjukkan spektrum metabolit dari voxel yang diukur

Unsur metabolik utama yang dinilai pada jaringan otak adalah choline/cho (penanda tumor), creatine/cr (nilai cr cenderung stabil pada spectrum), N-acetylaspartate/NAA (penanda jaringan normal), lipid dan lactate yang akan muncul pada kelainan tertentu. Unsur metabolik yang dihitung pada spektrum spektroskopi adalah integral (I) Area Under Cover (AUC) yaitu banyaknya kumpulan sinyal (NAA, Cho). Hasil pengukuran dan hasil hitung dari unsur-unsur metabolit akan dianalisa dan disimpulkan jenis tumornya oleh Dokter Spesialis Radiologi.

Prosedur pemeriksaan MR Spektroskopi kepala merupakan prosedur lanjutan dari pemeriksaan MRI Kepala dengan media kontras. Prosedur pemeriksaan MR Spektroskopi disebutkan tujuan dari pemeriksaan MR Spektroskopi Kepala adalah untuk menegakkan diagnosa tumor otak, grading tumor, membedakan antara tumor dan 
infeksi virus, serta untuk evaluasi tumor recurrence post teraphy.

Sekuens MR Spektroskopi menggunakan Multi Voxel Spectroscopy (MVS) dan Chemical Shift Imaging (CSI). Unsur-unsur metabolit yang dinilai pada MRS yaitu NAA, Choline, Creatine, Lipid, dan Lactate. Sedangkan yang dihitung dan dianalisa adalah integral Area Under Cover (AUC) yaitu banyaknya kumpulan sinyal (NAA, Cho).

Parameter TE yang digunakan pada sekuens MR Spektroskopi hanya intermediate TE $135 \mathrm{~ms}$, beberapa penelitian menyebutkan bahwa variasi dan kombinasi parameter TE dapat dilakukan dan mampu memberikan informasi unsur metabolit yang lebih lengkap, bahkan dapat digunakan untuk grading stadium tumor dengan lebih tepat. Perlu dilakukan kajian lebih lanjut dalam hal pengembangan variasi dan kombinasi parameter TE (short, intermediate, dan long TE) untuk mendapatkan informasi unsur metabolit tumor, sehingga grading tumor, biopsi jaringan tumor, serta identifikasi tumor recurrence dan jaringan yang muncul pasca terapi dapat dilakukan dengan tepat.

Prosedur pemeriksaan MR Spektroskopi hanya digunakan untuk menilai spektrum metabolit pada kasus tumor otak saja, belum digunakan pada kelainan patologis lainnya seperti epilepsi, neurogeneratif disease, stroke, infeksi, dan lainnya. Padahal menurut literatur MR Spektroskopi tidak hanya digunakan untuk mendiagnosa tumor otak saja, tetapi dapat juga digunakan untuk mendiagnosa kelainan di organ-organ lain.

\section{Daftar Pustaka}

Barker, P. B. (2001). N-acetyl Aspartate--A Neuronal Marker? Ann Neurol, 49(4), 423-424.

Gupta, R. K., Cloughesy, T. F., Sinha, U., Garakian, J., Lazareff, J., Rubino, G., Rubino, L., Becker, D.
P., Vinters, H. v, \& Alger, J. R. (2000).

Relationships Between Choline Magnetic

Resonance Spectroscopy, Apparent Diffusion

Coefficient and Quantitative Histopathology in

Human Glioma. J Neurooncol, 50(3), 215-226.

https://doi.org/10.1023/a:1006431120031

Hamsini, B. C., Reddy, B. N., Kumaran, Neelakantan, S., \& Palasamudram, S. (2018). Clinical Application of MR Spectroscopy in Identifying Biochemical Composition of the Intracranial Pathologies. New Developments in Neurotransmission Research. https://doi.org/10.5772/intechopen.71728

Herholz, K., Heindel, W., Luyten, P. R., DenHollander, J. A., Pietrzyk, U., Voges, J., Kugel, H., Friedmann, G., \& Heiss, W. D. (1992). In Vivo Imaging of Glucose Consumption and Lactate Concentration in Human Gliomas. Ann Neurol, 31(3), 319-327. https://doi.org/10.1002/ana.410310315

Horská, A., \& Barker, P. B. (2010). Imaging of Brain Tumors: MR Spectroscopy and Metabolic Imaging. Neuroimaging Clin N Am, 20(3), 293310.://doi.org/10.1016/j.nic.2010.04.003

Ionin, B. I., \& Ershov, B. A. (2014). The Fundamentals of NMR Spectroscopy.

Naser, R. K. A., Hassan, A. A. K., Shabana, A. M., \& Omar, N. N. (2016). Role of Magnetic Resonance Spectroscopy in Grading of Primary Brain Tumors. The Egyptian Journal of Radiology and Nuclear Medicine, 47(2), 577-

584.https://doi.org/https://doi.org/10.1016/j.ejrnm. 2016.03.011

Tognarelli, J. M., Dawood, M., Shariff, M. I. F., Grover, V. P. B., Crossey, M. M. E., Cox, I. J., TaylorRobinson, S. D., \& McPhail, M. J. W. (2015). Magnetic Resonance Spectroscopy: Principles and Techniques: Lessons for Clinicians. Journal of Clinical and Experimental Geaptology, 5(4), 320328. https://doi.org/10.1016/j.jceh.2015.10.006 Wh, S. (2010). Kanker The Silent Killer. Garda Media. 